\title{
Public INTEREST AS A CATEgory OF ADMINISTRATIVE AND LEGAL SCIENCE
}

EL INTERÉS PÚBLICO COMO CATEGORÍA DE LA CIENCIA JURÍDICA Y ADMINISTRATIVA

\author{
Tetiana Evgeniivna Kaganovska* \\ Iryna Anatiliivna Pakhomova** \\ Vladyslav Olegovich Neviadovskyi*** \\ Artem Oleksandrovych Yefremov ${ }^{* * * *}$
}

Abstract: The article examines the content and features of the public interest
as a category of administrative and legal science. The main features of public
interest are clarified, namely: (i) it is a set of certain needs (values); (ii) there
may be needs of the whole society, as well as its groups or individual
citizens; (iii) is provided at the initiative of the directly interested subject or
public administration; (iv) these interests are recognized by the state, can be
normatively fixed; (v) aimed at ensuring human rights and freedoms; (vi)
are provided by subjects of public administration. It is established that the
content of public interest as an administrative-legal category follows from
the essence of general interest and is individualized by the content of
administrative-legal relations. Public interest is defined as a set of certain
needs (values) of a person or society, aimed at ensuring and protecting

\footnotetext{
* Doctor of Legal Sciences. Professor. Rector of V. N. Karazin Kharkiv National University (Kharkiv, Ukraine). https://orcid.org/0000-0002-4427-2038. t.e.kaganovskaya@gmail.com ** Candidate of Legal Sciences. Associate Professor of the State and Legal Disciplines Department of the School of Law of the V. N. Karazin Kharkiv National University (Kharkiv, Ukraine). https://orcid.org/0000-0002-7161-3598. pakhomova@karazin.ua

*** Doctor of Law. Associate Professor. Deputy Dean of the Faculty No. 1 for Educational and Methodical Work of the Kharkiv National University of Internal Affairs (Kharkiv, Ukraine). https://orcid.org/0000-0002-3107-1464. vladon2309@ gmail.com

${ }^{* * * *} \mathrm{Ph} . \mathrm{D}$. Head of the Main Directorate of the State Tax Service in Kharkiv region (Kharkiv, Ukraine). https://orcid.org/0000-0001-7972-0323.art.efremov35@gmail.com
} 
human rights and freedoms and implemented in the activities of public administration. It is established that the public interest reflects the interests of society as a whole or an individual, but its needs may become significant for society as a whole. The types of public interests are distinguished depending on the sphere of realization, territory of distribution and number of persons expressing public interest.

Keywords: Public Interest, Administrative and Legal Relations, Private Interest, Public Administration, Sphere of Realization

Resumen: El presente artículo examina el contenido y los elementos del interés público como categoría de la ciencia administrativa y jurídica. En él se aclaran las principales características del interés público, tales como que: (i) es un conjunto de determinadas necesidades (valores); (ii) pueden darse necesidades de toda la sociedad, así como de sus grupos o ciudadanos a título individual; (iii) se presta a iniciativa del sujeto directamente interesado o de la administración pública; (iv) los intereses son reconocidos por el Estado, y pueden ser fijados normativamente; (v) están destinados a garantizar derechos humanos y libertades; y (vi) son prestados por sujetos de la administración pública. Se establece que el contenido del interés público, como categoría jurídico-administrativa, se deriva de la esencia del interés general y se individualiza por el contenido de las relaciones jurídicoadministrativas. Por ende, el interés público se define como un conjunto de determinadas necesidades (valores) de una persona o sociedad, encaminadas a garantizar y proteger los derechos humanos y las libertades, puestas en práctica mediante las actividades de la administración pública. Se establece que el interés público refleja los intereses de la sociedad en su conjunto o de un individuo, si bien sus necesidades pueden llegar a ser significativas para el conjunto social. A su vez, también se concluye que los tipos de intereses públicos se distinguen según el ámbito de realización, el territorio de distribución y el número de personas que expresan el interés público.

Palabras clave: Interés público, relaciones jurídicas y administrativas, interés privado, administración pública, esfera de realización

Summary. I. Introduction. II. Purpose and Assignments of the Study. III. Methodology. IV. Statement of the Main Material. V. Conclusion. References. 


\section{INTRODUCTION}

Strengthening the role of European Union (EU) civic institutions in Eastern Europe is often accompanied by the provision of equal financial and technical support to local civic institutions. The EU also uses a cooperation model based on partnerships between public authorities and civic institutions. This is mostly due to the willingness of local civic institutions to cooperate with external actors such as the EU, as well as with other civic society actors in Eastern Europe (Gryshchenko, et al., 2021, p. 798). The Constitution of Ukraine, having defined the human being, his life and health, honor and dignity, inviolability and safety as high social values, obliged state bodies to guarantee observance and promotion of civil rights and freedoms to the citizens. Thus, the main law established a "people-centered" approach in the activity of all subjects of power of authority, based on ensuring and protecting the rights, freedoms and legitimate interests of citizens. It is the interests of people, which conform to the current legislation and express the freedom of society, determine the content and focus of the activities of governmental-authoritative subjects. Achieving the results of public-service activity of the state, ensuring the priority of public interests is impossible without the development of relevant provisions of the administrative and legal science.

In terms of an in-depth study of current issues of administrative and legal science, it should be noted that its development is quite different depending on the country. The countries of the world with different quality have implemented certain provisions of administrative law into their state mechanisms. Ukraine, like any other country, has its history of development and formation as a modern state governed by the rule of law, including the genesis of administrative law (Haran, et al., 2020, p. 545). Exactly administrative law is a branch of law, which is able to build an effective system of the mechanisms to guarantee and protect the rights, freedoms and legitimate interests of an individual, ensure the proper interaction between the state and an individual, ensure the implementation of tasks of public administration system. Categories of administrative and legal science determine the main elements of the mechanism to ensure and implement rights, freedoms and legitimate interests of an individual. The leading place among such categories belongs to public interest. Nowadays, this legal category is indefinite and little researched, which specifies the relevance of its further study.

The content and peculiarities of administrative law and public interest have been studied by a number of leading Ukrainian scientists in the field of 
administrative law. Their works are devoted to the content of public law and interest, the distinction between public and private interests. At the same time, there is no unity of point of views on these issues among scientists. The content of public interest is not defined in the current legislation too. However, this legal category is important for law-enforcement activity, which determines the relevance and importance of the study of the content and peculiarities of public interest as an administrative and legal category.

\section{PuRPoSe AND ASSIGNMENTS OF THE STUDY}

The purpose of the study is to determine the content and peculiarities of public interest as an administrative and legal category on the basis of analysis of scientific works. To achieve mentioned goal, it seems necessary to analyze the scientific works of foreign and domestic scholars specializing in administrative law and determine the concepts and peculiarities of public interest, the criteria for distinguishing it from a private interest, as well as to classify public interests.

\section{METHODOLOGY}

Achieving results in any research activity is possible only with the use of a set of methods of scientific knowledge. The method is the basic category of research methodology. Scientists offer different classifications of research methods, but most opinions are divided into two groups: general and special. The difference between methodology and methods is that methodology is seen as a way of knowing, and the method as a way to study the phenomena of material reality. In general, the method is understood as a certain algorithm that establishes the sequence of use of certain tools to achieve this goal.

We believe that the decision on the choice of research methods should always correspond to the specifics of the topic, its subject, purpose and objectives. The search and bibliographic method provided a systematic search of bibliographic catalogs, electronic libraries on the Internet of literary sources on the topic of research.

Methodological basis of work consists of general scientific and special methods and techniques of scientific knowledge. Historical and legal method allowed us to determine the formation and development of the understanding of public interest as an administrative and legal category. Gnoseological method was used while clarify the concepts and 
characteristics of public interest. The usage of the comparative and legal method is the basis for distinguishing the categories of public and private interests. Structural and functional analysis was used in the classification of public interests.

\section{STATEMENT OF THE MAIN MATERIAL}

The European integration course of Ukraine, deepening the democratization of our society, asserting the priority of human rights and freedoms in relations with the subjects of state-power powers require the further development of the forms of judicial protection of the rights, freedoms and interests of individuals and legal entities, comprehensive growth of law enforcement and law enforcement administrative procedural form. The administrative process provides a dynamic form of life for one of the largest arrays of legal norms, which are substantive norms of administrative law, and which serve as a priority legal instrument for the implementation of tasks and functions of the executive power (Honcharuk $\&$ Tekedjanova, 2020).

Nowadays, one can confidently state that the implementation of quality public administration remains the key element in the state system functioning and its individual mechanisms of government. The experience of developed countries demonstrates that the transparency of the processes associated with the implementation of public administration is an integral attribute of the success of these processes. It also significantly increases the public's confidence both in the processes themselves and in the people who direct these processes (Serohina, et al., 2021, p. 281). Clearly defined administrative procedures will greatly help the government in establishing a regime of maximum assistance to government agencies and public associations. The government will be able to ensure the maintenance of the rule of law in Ukraine, which inevitably leads to increased efficiency of the entire state system. The norms that determine administrative procedures should become a reliable foundation for the positive legal activity of the subjects of power. If the authorities comply with certain requirements for the content and form of administrative procedures (their clarity, unambiguity and focus on effective protection of human and civil rights, freedoms and interests), the possibility of introducing such a management and decisionmaking system there will be arbitrariness, corruption or inefficiency. To some extent, such actions will also contribute to the establishment of better interaction both between government agencies and between government and citizens (Kikinchuk, 2020). 
Current international and national legislation determines that the activities of the state must be aimed at satisfying human interests, both private and public. The category of interest is quite often common in the legislation, but not a single normative and legal act gives its interpretation. There is no unambiguous definition in the administrative and legal science, and in this regard, it is advisable to start the study with its interpretations by other sciences.

Interest means inherent to the person attitude to someone, which expresses positive or negative orientation of his activism, activity, historical creativity on search, choice, usage or creation of ways, means, methods, norms, social institutions, capable to satisfy human requirements. That is, interest determines the content and orientation of human activity to meet certain requirements. Social interest is a category used by a number of social sciences to denote the reasons that direct the activities of social subjects to achieve certain results to the extent available to them (Nadolnyi, et al., 2011).

Exactly the emergence of interest usually contributes to a certain activity, determining the main directions and ways of achieving the desired results. In the humanities interest is interpreted as the concentration of person on the relevant external subject. It has the following features: (i) focus on a particular subject; (ii) intelligence importance and emotional interest in the subject; (iii) manifestation of interest provides attention; (iv) interest is related to the requirement, but does not coincide with it (Totyev, 2002, p. 20).

The content of the public interest as an administrative and legal category is a result of the essence of the general interest and is individualized by the content of administrative and legal relations. Under the latter in the science of administrative law is understood as public relations governed by administrative law, the subjects of which are endowed with rights and responsibilities in the field of ensuring the rights, freedoms and legitimate interests of individuals and legal entities, as well as in the process of public (state, self-government) management in the areas of socio-economic and administrative and political development and protection of public order (Kolomoiets, 2011).

Yu. P. Bytiak (2020, pp. 54-56), H. A. Honcharenko (2020, p. 117) distinguishes the following features (signs) of administrative and legal relations: (i) they are public legal relations; one of the parties is always the holder of legal authority, however, in addition to public administration bodies, the subjects may be other subjects of public and private law, if they are delegated state functions and powers; the transmission of functions to self-governing organizations and other public associations is not excluded; provided that these entities act in the public interest and perform state 
functions in the field of public administration, their relations are administrative; (ii) are relations of power and subordination and are determined by the inequality of the parties; (iii) the relations may arise on the initiative of either party; (iv) on the one hand, is a form of social relations, on the other hand, is a form of organizational relations, in the implementation of which the tasks of management are solved; (v) disputes are usually resolved in the administrative way; (vi) violation of the requirements of administrative law entails legal liability, sometimes the court procedure for prosecution is not excluded. Considering these features of administrative and legal relations, it should be noted that the public interest is the concentration and interest of a person in certain results of public administration in the relevant sphere of public life or activities to ensure the rights and freedoms of citizens. Its implementation almost always depends on the subject of public administration and is expressed in certain administrative and legal relations.

The science of administrative law has developed several positions on the interpretation of the content of public interest. Thus, Yu. Tikhomirov (1995, p. 55) formulates his author's definition as a combination of common interests, without satisfaction of which it is impossible to satisfy private interests, on the one hand, on the other hand, to ensure the integrity, permanence in the normal development of organizations, states, nations, social strata and society in general. As S. T. Honcharuk (2000, pp. 32-33) notes, public interest is the interest of a social community, recognized, satisfied by the state. Recognition of publicity interest is carried out by the method of its legal (law) support (fixation in the norms and establishment of the mechanism of implementation). This opinion is quite deliberative, since not always a public interest is expressed by group of people, it may come from one or several people. By its content public interest is important for a significant number of individuals and legal entities values (requirements), which in accordance with the legally established competence are provided by the subjects of public administration (Halunko, et al., 2018).

L. O. Zolotukhina $(2017$, p. 97; 2019) notes that the public interest should be understood as a combination of recognized by the state requirements, the implementation of which is guaranteed by means of public administration and contributes to ensuring human rights and freedoms. That is, scientists agree that the public interest is a combination of recognized and satisfied by the state requirements. At the same time, quite deliberative is the issue of quantitative characteristics of public interest. Most scientists note that it is the interest of a big number of subjects. At the same time, in practice public interest often expresses the requirements of one or more subjects, but potentially the whole society may be interested in it. 
The concept of public interests is relative, constantly developing and adapting to individual markets as a result of "market changes" and the development of knowledge (Banasiński \& Piontek, 2009). Interpretation of this legal category is also reflected in the works of foreign scientists. Thus, in the United States and Britain the public interest is traditionally considered as inseparable from the individual interests and is interpreted as a combination of individual interests (Zelentsov \& Nemytina, 2018, p. 427).

In the Brazilian literature it is proposed to consider the public interest as a combination of individual interests, which in their orientation coincide with the vital blessing, in their content is a certain material or moral value or benefit, which each individual wants to get or keep as a personal heritage and which acquire a public character, when this desire is supported and shared by as many people, as it begins to be identified as the dominant desire of the community (Gonzalez Borges, 2007). Public interest refers to a set of behaviors that obligate an organization not only to meet the requirements of citizens in public affairs, but also to behave in ways that benefit citizens through administrative decisions (Haddadi \& Raad, 2015). The public interest represents a set of values that society perceives as important and positive. Some of them can be found in legislation as mandatory laws, representing the freedom of society implemented by the legislator (the role of the political factor) (Zimmermann, 2014). "Conceptual instrument" representing the public interest (being the main element of the theory of administration, as well as the concepts of "administrative act" and "administrative discretion") should be obtained under the current substantive law: the public interest is a reflection of the current legislation (Raduła, 2017).

The signs of public interest are formed as to the legal category from position of approach of the systems: (i) a public character of public interests (setting of public interest); (ii) tie-up with mass character (quantitative aspect); (iii) confession from the side of the state and material well-being by a right (normatively envisaged, substantial social values are a soba or in general assumed by a right as a certain display of caring from the side of the state in regard to stability of law and order); (iv) possibility of their realization by means of measures of state-imperious character (Berestova, 2019).

Summarizing mentioned definitions, we can identify the main features of public interest, in particular: (i) it is a combination of certain requirements (values); (ii) there may be requirements of the whole society, as well as its groups or individual citizens; (iii) is provided at the initiative of the directly interested subject or public administration; (iv) these interests are recognized by the state, can be normatively enshrined; (v) aimed at ensuring the rights and freedoms of a person; (vi) are provided by subjects of public 
administration. Taking into account these features, the public interest can be defined as a combination of certain requirements (values) of person or society, aimed at ensuring and protecting human rights and freedoms and implemented in the activities of public administration.

The study of the content of public interest as an administrative and legal category requires the definition of the basic criteria and foundations of its differentiation from interest. To this issue in the science of administrative law has paid considerable attention, but today, scientists have not developed an unambiguous position on this issue. Thus, R. S. Melnyk and V. M. Bevzenko (2014, p. 36) think that private interests are satisfied with their own, exclusively intellectual actions and operations (for example, internal, non-objectifiable confession of a certain faith), as well as satisfied with their own physical actions, but not made public (for example, keeping an "intimate diary"). At that, such interests are not amendable to state-legal regulation. In contrast to private interests, public interests unite only those interests, which are equally important for each member of society (for example, the interest to breathe fresh air). That is, scientists think that the public interest is important for each member of society and is usually satisfied by the subjects of public administration, and private interest of a particular person or a clearly determined circle of persons satisfied by their own physical or intellectual actions.

The public interest is the sum of private interests, private or individual interests are part of the public interests, and there is no public interest outside the private interests. The formation of public interest consists of two kinds of interests, specifically private interests and common interests. Among these, the general interest is mainly a combination of partial interests derived from the personal interests of individuals and public organizations. Such interests should ensure the development of personal interests and, finally, serve the satisfaction of the individual (Zhao, 2018).

Traditional definitions of public interest as a general interest of society recognized by the state, and private interest as an interest of an individual recognized and protected by the state are now considered methodologically outdated and require new science-based approaches (Mykolenko, 2016). Not always the public interest is aimed at meeting the requirements of the whole society, but always meets the current legislation and is implemented by competent subjects within the framework of the performance of tasks and functions by state subjects. In modern pluralistic societies, the question of what is good for the general public and what constitutes a threat is often a focus of debates (Hauser, et al., 2013, p. 15).

According to R. A. Kaliuzhnyi and S. V. Petkov (2009, p. 4), in the basis of subjective public rights it is not hard to see guarantees of usage by 
a person a certain possibility to carry out legally significant actions at his discretion in the spheres of organization and implementation of socially important human relations guaranteed by appropriate standards. From private subjective rights of public nature are distinguishes by the fact that in relations, where they are formed and implemented, the obligatory party, besides the carrier of these rights, as a rule, acts a carrier of public authority - the subject of powers of authority.

Nowadays, scientists have expressed the position that the interest of an individual may not coincide with the interest of the state and conversely, but this does not affect their implementation within the limits established by law. At the same time there is a general demand of compliance with the law and implementation in order to ensure and protect the rights and freedoms or implementation of public administration. In this regard, it is necessary to determine the criteria by which it will be possible to distinguish between public and private interests, which in turn will contribute to a more effective public administration to meet and ensure the implementation of public interests, as well as to protect the rights of citizens in the implementation of private interests.

The main difference between them, as already noted, is whose requirements they reflect. Thus, the public interest reflects the interests of society as a whole or of the individual, but its requirements can become meaningful to the whole society. Such a common blessing as a value must be interpreted as a state of affairs, actual or potential, "as it ought to be". Therefore, it is important to preserve or implement it. It is an activity carried out in a well-considered direction and in accordance with an accepted axiology (Piechowiak, 2012). Private interests reflect the values of one person or a well-defined circle of people and are of no interest to people they do not concern. The next difference is that if the implementation of a public interest is ensured by its initiator and the subject of public administration, the private interest is ensured by its subjects and in exceptional cases the court. Public interests are quite often enshrined in the current legislation, which cannot be said about private ones. Although both are realized in accordance with the legislation and within the limits defined by it. The next difference is in the method of protection. Protection of public interest is carried out through the application of instruments of public administration and in court. Private interests can be protected either directly by its subjects, or in court.

In a 2012 report, the University of California Law Department proclaimed that the public interest may include the full range of substantive law. These rules can include civil rights requirements, poverty law, consumer law, environmental law, employee and employer law, 
immigration law, or even election law. In addition, it can include public action to improve the development of economic integration, public-private projects in the sphere of housing financial support, environmental protection, and important schools (Haddadi \& Raad, 2015, p. 24).

The theory of division of law into public and private law helps today to determine the role of the state as a public institution in the life of society and establish the limits of its interference in the economy, culture and other spheres of public life. At the same time, we believe that within administrative law methodologically it is not correct to use only the term "public interest", which simultaneously characterizes both state interests and public interests. If in administrative law will be clearly distinguished between state and public interests, it will allow to discover and draw attention to the new features of administrative and legal regulation of Ukraine in modern conditions (Mykolenko, 2016).

Disclosure of the content of public interest as an administrative and legal category is impossible without determining its main types, which can be distinguished by several criteria. Thus, in the sphere of implementation public interests can be classified into material, social, political, spiritual, cultural, educational, etc. Narrower directions of implementation of public interest can be distinguished in each of these spheres. At the same time, individual requirements can hook several spheres of public life.

According to the territory of distribution we can distinguish nationwide, regional and local public interest. It should be noted that nation-wide and regional interests do not always coincide. In practice, there are a number of examples when regional or local public interests contradict the state ones. For example, the public interests of national minorities living in a certain territory, regarding their national identity do not always coincide with the foundations of state policy in the relevant sphere.

Depending on the number of persons expressing the public interest, it can be divided into one-person and collective. At that, often the one-personal interest is transformed into the interest of a group of people or the whole society, which is connected with its importance in the sphere of public administration.

\section{CONCLUSION}

1. Summarizing the above-mentioned, we can conclude that the category of public interest, although appeared in the administrative and legal science not so long ago, but has taken in it an important place, determining 
the activities of public administration, contributing to the satisfaction and protection of human rights and freedoms in all spheres of social life.

2. The content of a public interest has been consisted of a totality of certain requirements (values) of an individual or society, aimed at ensuring and protecting human rights and freedoms and have been implemented in the activities of public administration.

3. Proper ensuring of the implementation of public interest has been determined the effectiveness of public administration. In administrative and legal science public interest has not been separated from private interest, which has been due to the fact that often private interests have formed public ones. At the same time, the interest of an individual may not coincide with the interest of the state and conversely, but this has not affected their implementation in the established by the law limits. At the same time there has been a general requirement of compliance with the law and implementation in order to ensure and protect the rights and freedoms or the implementation of public administration. 


\section{REFERENCES}

Banasiński, C., \& Piontek, E. (2009). Ustawa o Ochronie Konkurencji i Konsumentów. Komentarz. Lexis Nexis.

Berestova, I. E. (2019). Legal Category «Public Interest» From Position of Approach of Systems. Constitutional State, 33. Doi: https://doi.org/10.18524/24112054.2019.33.162015

Bytiak, Y. P. (2020). Administrative Law: Textbook. Pravo.

Gonzalez Borges, A. (2007). Supremacia do Interesse Público: Desconstrução ou Reconstrução? Revista Diálogo Jurídico, 15, 1-23.

Gryshchenko, I. M., Denysova, A. V., Ovsiannikova, O. O., Buha, H. S., \& Kiselyova, E. I. (2021). Means for Control Over the Activities of Public Authorities by Civic Democratic Institutions: The Conceptual Framework Analysis. Political Questions, 39 (69), 796-813. Doi: https://doi.org/10.46398/cuestpol.3969.49

Haddadi, M., \& Raad, M. M. (2015). The Status of Public Interest in Iranian Administrative Law. International Journal of Academic Research in Economics and Management Sciences, 4 (3), 23-30. Doi: http://dx.doi.org/10.6007/IJAREMS/v4-i3/1799

Halunko, V., Dikhtiieskyi, P., \& Kuzmenko, O. (2018). Administrative Law of Ukraine. Full course: Manual. OLDI-PLIUS.

Haran, O. V., Maksimentseva, N., Khrystynchenko, N., \& Povydysh, V. V. (2020). Foreign Science of Administrative Law and Possible Areas of Its Adaptation in Ukraine. Jurnal Cita Hukum (Indonesian Law Journal), 8 (3), 543-552. Doi: 10.15408/jch.v8i3.18301

Hauser, R., Niewiadomski, Z., \& Wróbel, A. (2013). System Prawa Administracyjnego. Pojęcie Administracji Publicznej. C.H. Beck.

Honcharenko, H. A. (2020). Administrative Relations in the Field of Security Sector Management: Concepts, Content and Characteristics. Law and Society, 2 (2), 114-121.

Honcharuk, S. T. (2000). Administrative Law of Ukraine. General and Special Parts: Manual. National Academy of Internal Affairs of Ukraine.

Honcharuk, S., \& Tekedjanova, K. (2020). Administrative Justice, Administrative Court Proceeding and Administrative Process: Conceptual-Categorical Dimension and Relation. Law Journal «Air and Space Law», 1 (54), 70-77. Doi: https://doi.org/10.18372/2307-9061.54.14542

Kaliuzhnyi, R. A., \& Petkov, S. V. (2009). Administrative Law of Ukraine: Legislative Definitions: Dictionary-Reference Book. KPU.

Kikinchuk, V. Y. (2020). Concepts, Features and Types of Administrative Procedures. Law and Safety, 77 (2), 64-68. Doi: https://doi.org/10.32631/pb.2020.2.08 
Kolomoiets, T. O. (2011). Administrative Law of Ukraine. Academician Course: Textbook. Yurinkom Inter.

Melnyk, R. S. (2014). General Administrative Law: Manual. Vaite.

Mykolenko, O. I. (2016). Public and Private Interests in Administrative Law. Constitutional State, 24, 100-104.

Nadolnyi, M. I., Burov, I. V., Aleksandrov, D. V., \& Martyniuk, I. O. (2011). Interest. In Ivan M. Dzjuba (Ed.), Encyclopedia of Modern Ukraine. Institute of Encyclopedic Research of the National Academy of Science of Ukraine.

Piechowiak, M. (2012). Dobro Wspólne Jako Fundament Polskiego Porządku Konstytucyjnego. Trybunał Konstytucyjny.

Raduła, M. (2017). The Interpretation of the Notion of Public Interest in Polish Public Competition Law According to the Judgement of the Court of Competition and Consumer Protection of February 4, 2015 (XVII AmA 163/11). Central and Eastern European Journal of Management and Economics, 5 (2), 131-145.

Serohina, S. H., Mykolenko, O. M., Seliukov, V., \& Lialiuk, O. (2021). Public Administration as One of the Forms for Exercising State Power. Jurnal Cita Hukum (Indonesian Law Journal), 9 (2), 279-290. Doi:

10.15408/jch.v9i2.21692

Tianyuan, Z. (2018). On the Limitation of Public Interest to Private Interest in Administrative Law Advances in Social Science. Advances in Social Science, Education and Humanities Research: Proceedings of the $4^{\text {th }}$ International Symposium on Social Science. Doi: https://doi.org/10.2991/isss-18.2018.120

Tikhomirov, Y. A. (1995). Public Law. Publishing House BEK.

Totyev, K. Y. (2002). Public Interest in Legal Doctrine and Legislation. State and Law, 9, 19-25.

Zelentsov, A. B., \& Nemytina, M. V. (2018). Public Interests and Legal Constructions Derived from Them. RUDN Journal of Law, 22 (4), 425-462. Doi: 10.22363/2313-2337-2018-22-4-425-462

Zimmermann, J. (2014). Prawo Administracyjne. Wolters Kluwer.

Zolotukhina, L. O. (2017). Content of Public Interest as an Administrative and Legal Category. Subcarpathian Law Herald, 1 (16), 94-97.

Zolotukhina, L. O. (2019). Public Interest as an Administrative and Legal Category. [Thesis for Obtaining a Doctor's Degree in Legal Sciences]. Zaporizhzhia National University, Zaporizhzhia, Ukraine. 